\title{
Examining The Mediating Effect Of Organizational Politics On Personal Traits And \\ Job Performance Relationship \\ Applied Study On Public Hospitals In Zagazig \\ City
}

Ola Mohamed El Azzazy Ahmed

Assistant lecturer -Business Administration

Department 


\begin{abstract}
The purpose of current research is to investigate the mediating role of organizational politics in the relationship between personal traits (political skills - locus of control - Machiavellianism) and job performance, and also investigating the direct impact of personal traits and organizational politics. Questionnaire was developed, and date collected from stratified simple random sample of nurses and physicians $(n=300)$ from four public hospitals in Zagazig city. Data was analyzed using AMOS V.20and results indicated that individuals with high political skills, high Machiavellianism and internal locus of control have more tendency to practice organizational politics, also it was found that organizational politics partially mediate the relationship between personal traits and job performance.
\end{abstract}




\section{ملخص البحث}

إستهاف البحث الحالي اختبار الدور الوسيط للتسييس التظيمي في العلاقة بين السمات الثخصية ( الميكافيلية ـ المهارات السياسية ـ موضع التحكم في الذات) من ناحية وبين الأداء الوظيفي من ناحية أخرى. كذلك استهف البحث الحالي اختبار التأثير المباثر للسمات

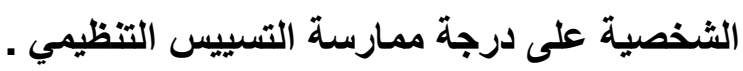
لتحقيق هلف البحث تم تجميع البيانات الأولية للاراسة الميدانية من خلال تصميم قائمة

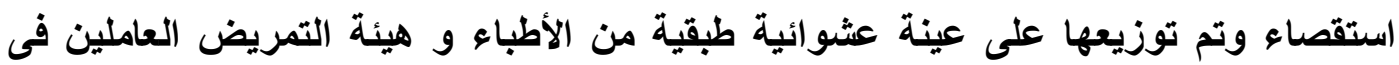
المستثفيات الحكومية وبمدينة الزقازيق ( مستثفى الرمد - مستثفى الصدر - مستثفى فئه الحميات ـ المستثفى العام). وقد تم إجراء التحليل الإحصائي للبيانات الأولية بواسطة برنامج AMOS الأفراد الأعلى في الميكافيلية والأعلى في المهارات السياسية و كذلك الأثخاص ذونه موضه التحكم في الذات الداخلي يكون لايهم ميل أعلى لممارسة سلوكيات التسييس التنظيمي ،أيضاً تم التوصل إلى أن التسييس التظيمي يتوسط جزئياً العلاقة بين السمات الثخصية والأداء الوظيفي للعاملين فى المستثفيات الحكومية بمدينة الزقازيق. 


\section{Introduction}

Political approach is one of the modern approaches to study organizations and interpreting its administrative processes and organizational behavior. According to this approach, organizations is defined as a political systems and a network of interdependent members who use power, influence and political maneuvering to control organizational resources (Bodla and Danish, 2013, Fairholm, 2009).

Despite the widespread acceptance of organizational politics presence as a real fact in any organization along four decades ago (Vigoda -Godat et al.,2003), a lot of researchers still investigate its meaning ,causes and consequence on the employees and the organizations as well (Raiz, 2013).

In this context, current study aims at identifying the personal traits that enhance practicing organizational politics behaviors in the Egyptian organizations in general and in an important service sectors which is public hospitals in particular.

\section{Research problem}

The health sector development is apriority in the Egyptian government's vision 2030 for achieving sustainable development (center of political and strategic studies, 2016). Although the increasing number of public and private hospitals in Egypt but the quality of services presented to patient -especially in public hospitals is unsuitable ( Rashad \& Ashraf , 2015).

One of the challenges to organizational development is employees' self- serving behavior, which may contradict interests of others and also the interests of their institutions. 
These behaviors have many harmful organizational consequences including high job stress (Azeem et al.,2010;Gbodamosi and Chinaka, 2011), high turnover intention (Sowmya and Panchanatham, 2012,zhang and lee, 2012), low job satisfaction (Gull and zaidi,2012;Malik et al .2009) and low organizational citizenship (Aam and probhakar,2010,Randall et al.1999).

Organizational politics behaviors reduce productivity by disrupting interpersonal relation among employees information sharing and organizational functions (Enyinna and Ndughu, 2014). It also interrupt organizational changes, because each individual try to protect his personal interests during change and gaining more privileges (Agboola and Salawu,2001).Organizational politics negatively affect achievement of organizational goals and harmony among organizational functional department (Olorunleke,2015).So that organizational performance can be enhanced by minimizing organizational politics behaviors.

Research importance 1-Academic importance

There is no agreement among scholars on the determinants of organizational politics in the related literatures, especially in the Arab countries Where cultural differences is expected to has important impact on employees' attitudes, practices and behaviors within the Organizations.

2-Empirical importance

Examining organizational politics behaviors in Egyptian organizations generally and specifically in hospitals which has especial 
concern form Egyptian government in its strategy (2030) to achieve sustainable development (center of political and strategic studies, 2016).

Current research will evaluate job performance of hospital staff (nurses-physicians) which is of central importance, because they are the direct medial service providers, and any negative practices conducted by them (self -serving behaviors) may affect patients' life directly or indirectly.

\section{Research objectives}

Current research aimed at achieving the following objectives:

1- Determining personal traits that contribute to practicing organizational political behavior in hospitals.

2- Determining the degree of practicing different patterns of organizational politics in hospitals.

3- Determining the impact of practicing organizational politics in hospitals on job performance in hospitals.

4- Measuring the mediating role of organizational politics in the relationship between individual determinants and job performance

\section{Theoretical framework}

The concept of organizational politics gained the attention of scholars along four decades as it has a lot of harmful consequences on the individual level and on the organizational level (Gbadamosi and Chinaka, 2011; Azeem et al.,2010). Organizational politics is asocial influence process and real fact in organizational life (Hochwater ,2012; Latif et al. 2011;Fairholm, 2009), according to (Allen et al , 1981), everyone in the organization subordinates as well as their managers practice organizational politics to influence decision making, resource allocation, setting goals, policies, and every day routines, (ferris et al.,2003; Bell et 
al.,2000; Appelbaum and Hughes, 1998).in this context organizational politics was defined as defined as intentional act of influence, not sanction by organization, that intended to promote or protect self-interests which is either consistent with or at the expense of others interests (Vigoda and Drory, 2016).

Organizational politics contradict the concept of organizational rationality (Boateng et al., 2013) which means that individuals decide their goals by keeping in view the organizational goals and interests, but a realistic picture of workplace life showed that the existence of conflicting goals between organizational members. Organizational politics is a tool to restore or maintain their sense of personal control over their organizational environment (Ene 2014).

Resent researched show that personal traits of individuals play important role in politics engagement and can reduce or enhance the effect of organizational politics on work outcomes (Hochwater and Treadway, 2003). Nevertheless there is scarcity in researches that identify individual personality traits difference and its effect on organizational politics engagement ( Van and Hassan,2017),through this part we will display the personal traits under concern of current research as follows:

Political skill, is important personality trait, it is a personal ability to understand others and to use this knowledge to influence others in ways that enhance achieving one's goals (Ferris, Treadway et al.,2007), so that politically skilled person has the ability to choose the behavioral patterns in the appropriate situations to influence others (Blickle, Oerder, and Summers,2010).According to Mintzberg (1983)the willingness is not enough but it's important to possess the ability to enact these behavior which is called political skill (treadway et al.,2005). Politically skilled individuals are more likely to enact influence behaviors by being able to 
effectively interpret social cues and have the ability to adopt their behavior to different contextual settings in order to achieve their goals (Ferris , Hochwater et al.,2002;Ferris et al.,2005).

Second personal trait of concern in current research is Machiavellianism .It is a negative personality traits that characterized by manipulation, opportunism and exploitation for achieving personal gain which is often against others' interests (Ali et al.,2009; O'connor.2001). Highly Machiavellianism employees have more tendency to practice organizational politics than others (Vall and Perrewe,2000).and they tend to interpret actions and events in political terms (Mudrack,1993). In this context many scholars found positive relation between Machiavellianism and organizational politics (Raiz, 2013;O'connor and Morison, 2001, Hochwater, Kacmar and witt, 2000) others confirmed that Machiavellianism is a predictor of perception of organizational politics (O'connor and Morrison, 2001;Stepanski et al.,2000;Ferris et al ,1989).

Third personal trait of concern in current research is locus of control is a type of personality that perceive themselves as being able to control their life's events and outcomes (El Badawy and Magdy , 2017), they have better social skills, more cleaver in setting goals and achieving them, and they have more successful career than others (Agarwal ,2016)they can easily adapt their behavior to reach their goals ,so they engage in organizational politics tactics more than others(Martin et al.,2005; Angeloua,2016).

Job performance is one of the most important dependent variables of interest to scholars (Rontundo and Rotman , 2002). Because employees performance is a significant indicator of overall organizational performance (Hafidz, Hoesni and Fatimah, 2012; Johar and Yahya,2012). Also ,job performance is part of human resources management it has 
important implications in formulating decisions related to rewards ,promotions, hiring, placement decisions and designing training programs needed ( Befort and Hattrup,2003).

The relationship between job performance and organizational politics is controversial .Most studies confirmed the negative relation between organizational politics and job performance (Abbas,2017; Imran,2017; Haroon, Hussain and Nawaz , 2017;, Vigoda, 2000; Zinta, 2005 and Brian, 2008 ), while more recent studies indicated the positive relation between organizational politics and job performance (Bodla, Afza, an Danish, 2014; yang,2017) specifically in a mechanistic structure operated units ( Zhang and Yang, 2012; Eldor, 2017).

\section{Research methodology}

Current research follow the deductive approach which depends on reviewing related literature and developing a set of hypotheses relate to the nature of the relationship between the research variables, and then testing the validity of hypotheses.

\section{Research hypotheses}

According to the previously displayed research problem, goals and theoretical back ground the research hypotheses are as follows:

H1: Personal traits (political skills-Machiavellianism -locus of control), have statistically significant direct impact on job performance in public hospitals.

This main hypothesis is subdivided into the following sub-hypotheses:

H11Political skills have statistically significant direct impact on job performance in public hospitals.

H12 Machiavellianism has statistically significant direct impact on job performance in public hospitals. 
H13Locus of control has statistically significant direct impact on job performance in public hospitals.

H2: Personal traits (political skills-Machiavellianism -internal locus of control) have statistically significant direct impact on organizational politics in public hospitals.

H3: Organizational politics have statistically significant direct impact on job performance in public hospitals.

H4: personal traits have statistically significant indirect impact on job performance through Organizational politics in public hospitals.

Measuring research variables:

Three types of variables used in current research; The independent variables are the personal traits, while the dependent variable is job performance, and finally the Mediator is organizational politics.

Table (1)

Personal traits Affecting Organizational Politics in Organizations

\begin{tabular}{|l|c|}
\hline \multicolumn{1}{|c|}{$\begin{array}{c}\text { Studies connected between the variable and } \\
\text { organizational politics }\end{array}$} & Variable \\
\hline $\begin{array}{l}\text { (Riaz, 2013) (Atinc et.al., 2010) (Boru,Islamoglu,2007) } \\
\text { (O'Connor,Morrison,2001) (Kacmar Et.Al.,1999) } \\
\text { Valle, 1995) }\end{array}$ & (Machiavellianism) \\
\hline $\begin{array}{l}\text { (Ross ,2014) (Kapoutsis et. al., 2011) (Jam et. al.2011) } \\
\text { (Treadway et. al., 2005)( Brouer, Harris And } \\
\text { Kacmar, 2011) (Cheema, 2010) }\end{array}$ & (Political Skill) \\
\hline $\begin{array}{l}\text { (Atinc et.al., 2010) (Boru,Islamoglu,2007) } \\
\text { (O'Connor,Morrison, 2001) (Valle, 1995) }\end{array}$ & Locus of control \\
\hline $\begin{array}{l}\text { (Valle,1995)(Kacmar et al ,1999) (Ohshima et } \\
\text { al.,2016) }\end{array}$ & Self- monitoring \\
\hline (Valle,1995)( Valle and perrewe,2000) & Need for power \\
\hline
\end{tabular}

Source: prepared by researcher according to previous literature review 
The previous table summarized the personal traits previously examined in organizational politics literature. It indicated that Machiavellianism and political skills, locus of control were among the most influential determinants of organizational politics.So they will be of concern in current research as independent variables.

Questionnaire is the main tool for collecting primary data this questionnaire prepared specifically for current study, where questionnaire to measure determinants is a modified scale of Machiavellianism (MachIV) , scale of political skills (Ferris et al., 2005), scale of locus of control (Byrne, 2011).

Questionnaire for measuring job performance is the modified scale of (Griffin et al.,2007), according to which job performance is subdivided into three dimensions ; task proficiency ,adaptability and initiatives.

Questionnaire for measuring actual organizational politics behaviors. organizational politics used to measure depending on Kamar and ferris (1991) scale which revised later on by Kacmar and Carlson (1997) his scale was generally accepted measure of organizational politics. Current research depends on measuring research organizational politics by scale designed by researcher, which is a modified the scale of (Zanzi and O'Neil, 2001) and ( Appelbaum and Hughes, 1998) and Kacmar and Carlson (1997).

The initial copy of the questionnaire was evaluated by a group of academic experts in management science and the suggested adjustments have been made based on their feedback. Then questionnaire distributed on research sample and its statistical total reliability was $(\mathbf{0 . 8 8 0})$ which is statistically acceptable. 
Research community and sample

This research will be applied on public hospitals in Zagazig city, there are four public hospitals only in zagazig city (General hospital Fever hospital- Ophthalmic hospital - Chest hospital).

As there are two sampling groups, stratified simple random sample of (nurses and physicians) in those four public hospitals in zagazig city will be selected to measure the degree of practicing organizational politics behavior in their workplace and its implications on employees' job performance.

Table(2)

Population and sample size

\begin{tabular}{|c|c|c|c|c|c|c|}
\hline Category & $\begin{array}{l}\text { General } \\
\text { hospita } \\
\text { l }\end{array}$ & $\begin{array}{l}\text { Fever } \\
\text { hospita } \\
\text { l }\end{array}$ & $\begin{array}{l}\text { Ophthalmic } \\
\text { hospital }\end{array}$ & $\begin{array}{l}\text { Chest } \\
\text { hospital }\end{array}$ & Total & \\
\hline physicians & 428 & 47 & 36 & 87 & 598 & \multirow[b]{3}{*}{1387} \\
\hline Percentage & $71.5 \%$ & $8 \%$ & $6 \%$ & $14.5 \%$ & $43 \%$ & \\
\hline Nurses & 504 & 135 & 91 & 59 & 789 & \\
\hline Percentage & $64 \%$ & $17 \%$ & $12 \%$ & $7 \%$ & $57 \%$ & \\
\hline $\begin{array}{l}\text { Sample of } \\
\text { physicians }\end{array}$ & 92 & 10 & 8 & 19 & 129 & \multirow[b]{2}{*}{300} \\
\hline $\begin{array}{c}\text { Sample of } \\
\text { nurses }\end{array}$ & 109 & 29 & 21 & 12 & 171 & \\
\hline
\end{tabular}

Source: prepared by the researcher depending on Records of the Directorate of Health Affairs in Sharkia, and based on statistical table of determining sample size.

\section{Research limitations}

\section{1-Empitical limitations}

This research will be applied on public hospitals in Zagazig city rather than private hospitals, where previous studies approved that 
organizational politics is higher in public organizations rather than in private organizations (Arogundade et al.,2016; Bodla and Dainish,2008). 2-Objective limitations

Current research concentrates on actual organizational politics behaviors rather than perception of organizational politics where actual organizational politics behaviors are results of perception and many other individual and situational factors. in this context (Singh, 2016) and (Mathur And Gupta, 2012) argued that our behavior is not only a function of our perceptions, personality, values, and preferences, but also of the situation.

Personal traits will be the concern of current research rather than organizational factors and demographic variables .where there is scarcity in researches that identify personal traits and it has important impact on on organizational politics engagement (Van and Hassan2017), while organizational factors have studied extensively, and demographic variables has little or no effect on practicing organizational politics(Antic and Darrat, 2010).

\section{Statistical analysis}

Data analyzed using AMOS v20 it's a specific package of structural equation modeling which is a comprehensive statistical approach that applies set of regression equations simultaneously to determine the direct and indirect relationships between research variables.

Measuring scale reliability and validity

Current research used the internal consistency method to test scale reliability to evaluate the degree of questions clarity and homogeneous between statements measuring each variable as indicated in (table 3) as calculated by SPSS program. Results indicated high internal consistent 
reliability all values of alpha Cronpach ranged from (0.776 to 0.919$)$, which indicated that this scale will provide the same results each time measurement is repeated.

Table (3)

Internal consistent reliability

\begin{tabular}{|l|c|c|}
\hline Constructs & No.of statements & Alpha Crompach \\
\hline Political skills & $\mathbf{6}$ & $\mathbf{0 . 8 9 7}$ \\
\hline Machiavellianism & $\mathbf{4}$ & $\mathbf{0 . 7 7 6}$ \\
\hline locus of control & $\mathbf{4}$ & $\mathbf{0 . 8 0 4}$ \\
\hline $\begin{array}{l}\text { Organizational } \\
\text { politics }\end{array}$ & 15 & $\mathbf{0 . 9 5 3}$ \\
\hline Job performance & 10 & $\mathbf{0 . 9 1 9}$ \\
\hline Total reliability & $\mathbf{3 9}$ & $\mathbf{0 . 8 8 0}$ \\
\hline
\end{tabular}

Results of structural equation modeling:

The research hypotheses are tested statistically using AMOSv20 . It's a special package of structural equation modeling, which is considered a comprehensive statistical approach to test the relationship between latent variables and observed variables by analyzing set of regression equations simultaneously ,to test the direct relationship between independent variables (political skills-Machiavellianism- internal locus of control) and job performance and simultaneously with the indirect relationship between independent variables (political skillsMachiavellianism- internal locus of control) and job performance through organizational politics. The relationship examined by the program illustrated in figure (1): 


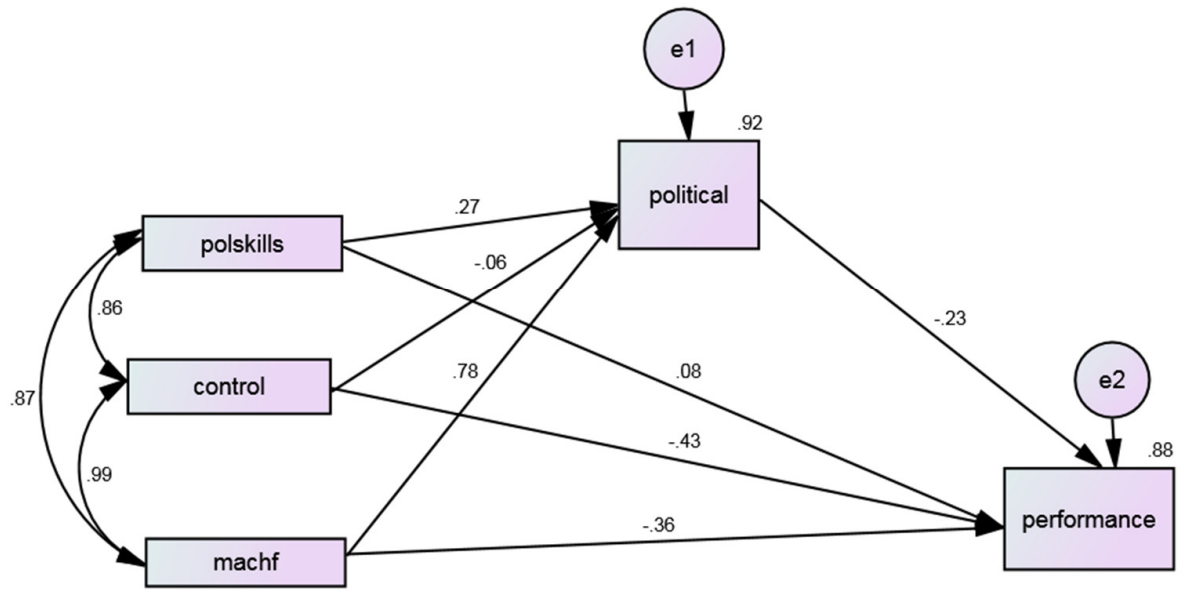

Figure (1)

Table (4)

Impact Of individual Determinants And Job Performance

\begin{tabular}{|c|c|c|c|c|}
\hline $\begin{array}{c}\text { Independent } \\
\text { variables }\end{array}$ & St. beta & T-value & Sign & $\begin{array}{c}\text { Dependent } \\
\text { variable }\end{array}$ \\
\hline Political skills & 0.08 & 1.208 & 0.026 & \multirow{3}{*}{$\begin{array}{c}\text { Job } \\
\text { performance }\end{array}$} \\
\hline Locus of control & -0.36 & -1.938 & 0.000 & \\
\hline Machiavellianism & -0.43 & -0.530 & 0.709 & \\
\hline
\end{tabular}

Analysis of results shown in table ( 4 ) reveal that.

Political skills have statistically significant impact on job performance $[\mathrm{T}$-value $=1.208, \beta=0.08$ with $P=0.026]$.Considering the statistical finding it can be said that individuals with high political skills have better job performance than others, therefore hypothesis $\mathrm{H}_{11}$ is strongly supported. 
Regarding locus of control, it has statistically significant impact on job performance [T-value $=\mathbf{- 1 . 9 3 8 ,} \beta=\mathbf{- 0 . 3 6}$ with $P=0.000]$. which confirm results of previous studies, which found that external locus of control view work environment negatively they blame circumstances, luck and environmental factors for their failure or negative outcomes which in turn negatively affect job performance (Ng and Sorensen, 2008, Kodisinghe, 2010). Therefore hypothesis $\mathrm{H}_{12}$ is supported.

With respect to Machiavellianism results reveal that it has not statistically significant relationship with Job performance [T-value =0.530, $\beta=-0.43, P=0.709]$, which means that hypothesis $H_{13}$ is not supported.

The previous table indicated that path coefficient between personal traits (political skills, Machiavellianism , internal locus of control)and job performance are all negative except for political skills, which means that highly politically skilled employees with internal locus of control have

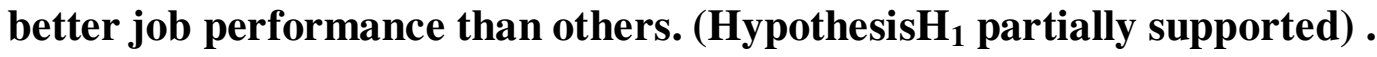

Table (5)

Impact of individual determinants on organizational politics.

\begin{tabular}{|c|c|c|c|c|c|}
\hline $\begin{array}{l}\text { Independent } \\
\text { variables }\end{array}$ & St. beta & T-value & Sign & $\mathbf{R}^{2}$ & $\begin{array}{l}\text { Dependent } \\
\text { variable }\end{array}$ \\
\hline Political skills & 0.27 & 7.132 & 0.030 & \multirow{3}{*}{0.67} & \multirow{3}{*}{$\begin{array}{l}\text { Organizational } \\
\text { politics }\end{array}$} \\
\hline Locus of control & -0.06 & -3.261 & 0.001 & & \\
\hline Machiavellianism & 0.78 & 0.810 & 0.012 & & \\
\hline
\end{tabular}

Analysis of results shown in table (5) reveal that.

Individual determinants both political skills and Machiavellianism have statistically significant positive impact on organizational politics, which means that individuals with higher political skills and high Machiavellianism traits have more tendency to practice organizational 
politics behavior more than others .Therefore hypothesis $\mathrm{H} 21$ and $\mathrm{H} 23$ is strongly supported.

Regarding locus of control, it has statistically significant negative impact on organizational politics $[\mathrm{T}$-value $=-\mathbf{2 . 3 0 4}, \beta=-\mathbf{0 . 2 4 1}$ with $\mathrm{P}=$ 0.02], the negative sign refers to the internal locus of control, So we can conclude that employees with external locus of control have low tendency to engage in organizational politics behavior than others on the other side individuals with internal locus of control have low tendency to engage in organizational politics behavior. They are able to adapt and change their behaviors easily to achieve their goals (Angelova, 2016), and also they are able to engage in more upward influence tactics with their mangers compared to those with external locus of control (Martin etal.,2005), therefore hypothesis $\mathrm{H} 22$ is supported.

The value of coefficient of determination $R 2=0.67$ as revealed in Table (5) which means that all independent variables both organizational and individual determinants explain about $(67 \%)$ of variance in practicing organizational politics behaviors, therefore hypothesis $\mathrm{H} 2$ is strongly supported.

Table (6)

Impact of organizational politics and job performance.

\begin{tabular}{|l|c|c|c|c|}
\hline $\begin{array}{c}\text { Independent } \\
\text { variables }\end{array}$ & St. beta & T-value & Sign & $\begin{array}{c}\text { Dependent } \\
\text { variable }\end{array}$ \\
\hline Politics & $\mathbf{- 0 . 2 9 8}$ & $\mathbf{- 1 . 7 0 1}$ & $\mathbf{0 . 0 1 8}$ & Job performance \\
\hline
\end{tabular}

Analysis of results shown in table ( 6 ) reveal that.

There is a statistically significant negative direct impact of organizational politics on job performance. Thus [T-value $=-\mathbf{1 . 7 0 1}, \beta=$ 0.298 with $P=0.018$, therefore $H 3$ is strongly supported, which means that as employees practice more organizational politics their job 
performance will decrease; as they depends on organizational politics behaviors and to achieve self-interests and privileges in the organization rather than through serious work.

Table (7)

The indirect impact of independent variables on job performance

\begin{tabular}{|l|l|l|l|l|l|}
\hline $\begin{array}{l}\text { Independent } \\
\text { variables }\end{array}$ & St. beta & Sign. & Mediating & Dependent & $\mathbf{R}^{2}$ \\
\hline Political skills & $\mathbf{0 . 0 4 2}$ & $\mathbf{0 . 0 4 7}$ & politics & Job \\
performance & $\mathbf{0 . 8 5}$ \\
Locus of control & $\mathbf{- 0 . 0 3 3}$ & $\mathbf{0 . 0 2 8}$ & & & \\
\hline Machiavellianism & $\mathbf{0 . 0 1 0}$ & $\mathbf{0 . 0 6 1}$ & & & \\
\hline
\end{tabular}

Table (7) indicates that independent variables have statistically significant indirect relationship with job performance except Machiavellianism haven't significant relationship with job performance where it has $(\mathrm{P}$-value $>\mathbf{0 . 0 5})$.

Job performance and both political skills and locus of control has significant relationship in the direct model and in the indirect model through organizational politics; which mean that organizational politics has partial mediating effect in the relationship between independent variables and job performance, which means that hypothesis $\mathrm{H} 4$ is strongly supported.

Table (8)

Direct, indirect and total effects among research variables.

\begin{tabular}{|l|c|c|c|}
\hline \multicolumn{1}{|c|}{ Effect } & Direct & $\begin{array}{c}\text { Indirect through } \\
\text { politics }\end{array}$ & Total \\
\hline Political skills $\rightarrow$ performance & $\mathbf{0 . 0 8}$ & $\mathbf{0 . 0 4 2}$ & $\mathbf{0 . 1 2 2}$ \\
\hline Locus of control $\rightarrow$ performance & $\mathbf{- 0 . 3 6}$ & $\mathbf{- 0 . 0 3 3}$ & $\mathbf{- 0 . 3 9 3}$ \\
\hline Machiavellianism $\rightarrow$ performance & $\mathbf{- 0 . 4 3}$ & $\mathbf{0 . 0 1 0}$ & $\mathbf{- 0 . 4 2}$ \\
\hline Politics $\rightarrow$ performance & $\mathbf{- 0 . 2 9 8}$ & & \\
\hline
\end{tabular}

All values are significant at $p$-value $<0.05$. 
Table (8) indicated that independent variables have a joint indirect impact on job performance through organizational politics which causes an increase in the standardized total effect. For political skill and internal locus of control except for Machiavellianism, which means that organizational politics mediate the relation between personal traits (political skills and internal locus of control) and job performance

\section{Conclusion}

Generally; employees engage in organizational politics when they perceive little or no control on their work environment, and also to protect or maximize their shot term or long term interests within the organization (Fairholm ,2009;Abbas, 2017) .

Some personal traits increase the tendency of employee to engage in organizational politics within organization (O'connor,2001), according to the quantitative analysis and results of the hypotheses testing there is a significant impact of personal traits and organizational politics on job performance in public hospitals in Zagazig city, Collectively, external locus of control has negative impact on job performance, also political skills have significant positive relationship with job performance, while Machiavellianism don't have significant relationship with job performance.

Moreover considering each independent variable, this research concludes that employees with high political skills ,high Machiavellianism and internal locus of control have more tendency to practice organizational politics than others. Finally current research found that organizational politics partially mediate the relationship between personal traits ( political skills and internal locus of control) and job performance. 


\section{Recommendation}

Its agreed upon that organizational politics can't be eliminated but it can be minimized. Current research presents some mechanisms to minimize organizational politics as follows:

1- Providing managerial training to hospital administrative leadership to understand organizational politics and its effect on employee's performance and other work outcomes.

2- Provide managerial training to leadership in hospitals on how to manager organizational political practices.

3- Provide managerial training on how to deal with informal groups (coalitions) within organization they affect decision making processes and affect achieving organizational goals.

4- Focusing on team works to perform work related tasks reduce employees self- serving behavior instead of that they focus on achieving team goals.

5- Increasing congruence goals between employees and their organization which in turn increase commitment toward organizational goals.

6- Machiavellianism personality has more likelihood to be involved in organizational politics behavior, so that personality tests must be conducted prior to employment and avoid hiring such individuals for the best of their organizations 


\section{References}

1. Abbas, Q. and Awan, S. H.(2017), Impact of organizational politics on employee performance in public sector organizations, Pakistan Administrative Review Vol. 1, No. 1, pp. 19-31.

2. Agboola, A. and Salawu, R.(2011), managing deviant behavior and resistance to change, international journal of business and management , Vol.6,No.1,pp.235-242.

3. Ahmed ,J. Hashmi, M.S., And Akhtar, H.M.(2016), Effect Of Organizational Politics On Job Performance : The Mediating Role Of Emotional Intelligence, Journal Of Social Science, Vol.10, No.1, Pp.96-107.

4. Arogundade,O.T., Arogandade, A.B. And Gbadijo,O.(2016), The Influence Of Perceived Organizational Politics On Workplace Incivity Among Private And Public Employees In Ogun State , Nigeria ,Canadian Social Science, Vol.12, No.5,Pp.40-45.

5. Blickle ,G., Oerder,K. , Summers, J.K.(2010), The impact of political skill on career success of employees' representatives, Journal of Vocational Behavior, Volume 77, Issue 3, Pp. 383-390.

6. Bodla, M.A., Danish, R.Q.(2013), The Use Of Influence Tactics In Politicized Organizations: A Look From Gender Perspective, Information Management And Business Review ,Vol. 5, No. 9, Pp. 456-462.

7. Bodla,M.A., Danish, R.Q.(2008), The Perceptions Of Organizational Politics And Work Performance: Exploring The Differences In Public And Private Sector, The International Journal of Knowledge, Culture And Change Management, Volume 8, Number 4,Pp.123-131. 
8. El Badawy, T.A. (2017), Exploring The Relationship Between Impression Management, Emotional Intelligence And Locus Of Control: Evidence From Egypt, International Journal Of Human Resource Studies , Vol. 7, No. 1,Pp. 20-37.

9. Enyinna,K., Ndughu,M. (2014), organizational politics and productivity in public sector, journal of business and management, no.16,issue 7, pp.65-70.

10.Fairholm, G.W. (2009), Organizational Power Politics: Tactics In Organizational Leadership, Second Edition ,California :Greenwood Publishing Group.

11.Ferris, G.R., Treadway ,D., Kolodinsky, R., Hochwarter, W., Kacmar, C., Douglas, C. (2005). Development And Validation Of The Political Skill Inventory. Journal Of Management, No. 31,Pp. 126-152.

12.Ferris, G.R., Treadway, D.C., Perrewé, P.L., Brouer, R.L., Douglas, C., \& Lux, S. (2007), Political Skill In Organizations, Journal Of Management, Vol.33,No.3,Pp. 290-320.

13.Griffin, M.A., Neal ,A., Parker ,S.(2007), Anew Model Of Work Role Performance :Positive Behavior In Uncertain And Independent Context, Academy Of Management, Journal , Vol.5, No, 3, Pp.327347.

14.Hafidz, S. W. M. , Hoesni, S. M. \& Fatimah, O.(2012), The Relationship between Organizational Citizenship Behavior and Counterproductive Work Behavior, Asian Social Science Vol. 8, No. 9, pp.32-37.

15.Haroon ,A.Hussain, Y. And Nawaz, M.(2017), The Influence Of Perceived Organizational Politics On Employees Performance : 
Acase Study Of Lohare, Pakistan , American Journal Of Social Science Research, Vol.3, No.3, Pp.7-11.

16.Hochwarter, W. A. (2003). The Interactive Effects Of Pro-Political Behavior And Politics Perceptions On Job Satisfaction And Affective Commitment. Journal Of Applied Social Psychology, 33, pp.1360-1378.

17.Hochwarter,W.A.; Ellen ,B.P.; Ferris, G.R. (2014), Examining the interactive effects of accountability, politics, and voice, Career Development International, Vol. 19 Issue: 4, pp.358-380.

18.Imran , M. ,Alishah,S.M. And Jehangir (2017), Organizational Politics And Work Outcomes Moderating Role Of Top Management Political Skills, Journal Of Business And Tourism,Vol.3,No.2, Pp.205-213.

19. Integration. Journal of Applied Psychology, 90(5), 225-254

20.Kacmar, K. M., Bozeman, D. P., Carlson, D. S., \& Anthony, W. P. (1999). An examination of the Perceptions of Organizational Politics Model: Replication and extension. Human Relations, 52(3), 383-416.

21.Mathur, S.K. And Gupta, S.K. ( 2012), Outside Factors Influencing Behavior Of Employees In Organizations, International Journal Of Information And Education Technology, Vol. 2, No. 1., Pp48-50. 22.O'connor ,W.E., And Morrison,T.G. (2001), A Comparison Of Situational And Dispositional Predictors of Perceptions of Organizational Politics, The Journal Of Psychology,Vol.135, No. 3,Pp. 301-312 .

23. Ohshima,R., Miyazaki,G., Haga,S. (2016),Effect of SelfMonitoring on Perceptions of Organizational Politics and Political Skill:Focusing on Two-Dimensions in Self-Monitoring, Volume 25 Issue 2 Pages 135-150. 
24.Olorunleke,G.K.(2015), effect of organizational politics on organizational goals and objectives, international journal of Academic Research In Economic And Management Science, Vol45,No.3, Pp. 59-70.

25.Rahman , S.Hussain, B. , Haque, A.(2011) Organizational Politics On Employees Performance :An Exploratory Study On Readmade Garments Employees In Bangladish, Business Strategy Series, Vol.12, Issue:3, Pp.146-155.

26.Raiz, A. And Akbar, A.(2013), Antecedents Of Organizational Politics: Evidence From Pakistan Public Sector , Actual Problems Of Economics, Issue 5, Vol.143, Pp.442-451.

27.Rotundo, M., \& Rotman, J. L. (2002). Defining and Measuring Individual Level Job Performance: A Review and Integration. Journal of Applied Psychology, vol.90,No.5,pp. 225-254.

28. Rotundo, M., \& Rotman, J. L. (2002). Defining and Measuring Individual Level Job Performance: A Review and

29.Singh,J.P.(2016), Factors That Influences Human Behavior At Workplace: An Overview, Sopaan-Ii, Volume 1, Issue 1, Pp.12-17.

30.Vall, M. And P.L. Perrewe, 2000. Do Politics Perception Relate To Political Behaviors? Tests Of An Implicit Assumption And Expanded Model. Hum. Relat., 53: 359-386.

31.Valle, M.(1995), individual determinants of organizational politics : perception and actions, a dissertation submitted in partial fulfillment of the requirement for the degree of doctor of philosophy , department of management, college of business, Florida state university. 
32. Valle, M., \& Perrewe, P. L. (2000). Do politics perceptions relate to political behaviors?: Tests of an implicit assumption and expanded model. Human Relations, 53(3), 359-386.

33.Van ,T.M., Hassan ,H.(2017), the role of personality on relationship between perceived organizational politics and turnover intention, international journal of business management, vol.2,issue. 2,pp.1-19.

34.Vratskikh,I., Masa'deh,R. , Al-Lozi1, M. \& Maqableh, M. (2016), The Impact of Emotional Intelligence on Job Performance via the Mediating Role of Job Satisfaction, International Journal of Business and Management; Vol. 11, No. 2,pp.69-91.

35.Zanzi, A., \& O'Neill, R. M. (2001). Sanctioned versus non-sanctioned political tactics. Journal of Managerial Issues, 13, 245-262.

36.Zieton ,N.A.(2018), Impact Of Governance On Health Sector (Comparative Study),Thesis Submitted For Doctor Of Philosophy Degree In Economics, Faculty Of Commerce, Zagazig University. 